\title{
Data on Biogas Production Quality: Evidence from the Wastewater Treatment Plant of Durrës
}

\author{
Stela Sefa, Tania Floqi, and Julian Sefa
}

\begin{abstract}
The wastewater treatment plant (WWTPD) located in Durrës, responsible for a treatment area of 205,000 inhabitants, employs the tertiary advanced wasterwater treatment to generate biogas from activated sludge for self use. The biogas collected from the anaerobic digestion tank feed the boiler and the co-generation unit which is then transformed to power its own energy grid. In order to evaluate the quality of biogas produced by anaerobic digestion of WWTPD's sludge, is measured the percentage of $\mathrm{CH}_{4}$ and $\mathrm{CO}_{2}$ from the biogas production during a three years period $(2016-2018)$.

From the performed analyses has resulted a percentage of $\mathrm{CH}_{4}$ up to $75 \%$ and $25 \% \mathrm{CO}_{2}$ in 2016. While the lowest percentage of $\mathrm{CH}_{4}$ in 2018 with respectively $70 \% \mathrm{CH}_{4}$ and $30 \%$ CO2.

Based on the value measurements, qualitative results of biogas parameters show that physicochemical and biochemical processes are performed under strict conditions and anaerobic digestion is performed according to standards.
\end{abstract}

Index Terms - wastewater treatment plant, biogas, methane, anaerobic digestion, sludge.

\section{INTRODUCTION}

The wastewater treatment plant (WWTPD) is located $2 \mathrm{~km}$ away from the city centre of Durres and treats urban wastewater of 205,000 inhabitants [1]. WWTPD employs the tertiary advanced biological treatment. The deployed technology is with active sludge with advanced treatment for nitrogen and phosphorus reduction. Biogas obtained from anaerobic digestion of WWTPD's sludge feed the boiler and the co-generation unit and is used to satisfy the needs of the plant with electricity.

The plant has been designed to treat a total flow-rate of $60,000 \mathrm{~m}^{3} / \mathrm{d}$. All the flow-rate is preliminary treated (screening, de-sanding) before been divided in the pretreatment over-flow, where only $30,000 \mathrm{~m}^{3} / \mathrm{d}$ goes to the further conventional treatment, while the remaining is discharged to the wetland [2]. The sewage arrives to the inlet pumping station where it is screened through coarse screens and pumped to the pre-treatment. In the pre-treatment, Ferric Chloride is also added to remove the phosphorous in the following stages. The final section of the pre-treatment facilities is a diversion unit, which divides the flow-rate to the four lines of the aeration tank. But only two lines of aeration tanks worked because of low flow-rate in this three year of

Submitted on May 21, 2021.

Published on June 12, 2021.

Stela Sefa, Department of Engineering Science, Faculty of Professional Science, Aleksandër Moisiu University of Durrës, Albania.

(e-mail: stelasefa@gmail.com) study period. The core of the treatment plant is the activated sludge process.

Once the wastewater had received sufficient treatment, excess mixed liquor is discharged into settling tanks and the treated supernatant is run off to undergo further treatment before discharge. Part of the settled material, the sludge, is returned to the head of the aeration system to re-seed the new wastewater entering the tank. Excess sludge is removed from the treatment process to keep the ratio of biomass to food supplied in the wastewater in balance and is pumped to the thickening stage. Into the gravity sludge thickener tanks, the sludge is mixed and agitated gently forming a solids blanket on the bottom of the tank. Solid's concentration achieved by gravity thickeners were typically $2 \%$ solids from waste activated sludge. The sludge from the bottom is pumped to the anaerobic digestion tanks. WWTP of Durres has two anaerobic digestion tanks, but in the three years of study only one of the digester tanks has worked. The process used in digester is single-stage mesophilic continuous system. The biogas is collected from the anaerobic digestion and accumulated in the gas-holder tank to feed the boiler and the co-generation unit which is then transformed to power its own energy grid.

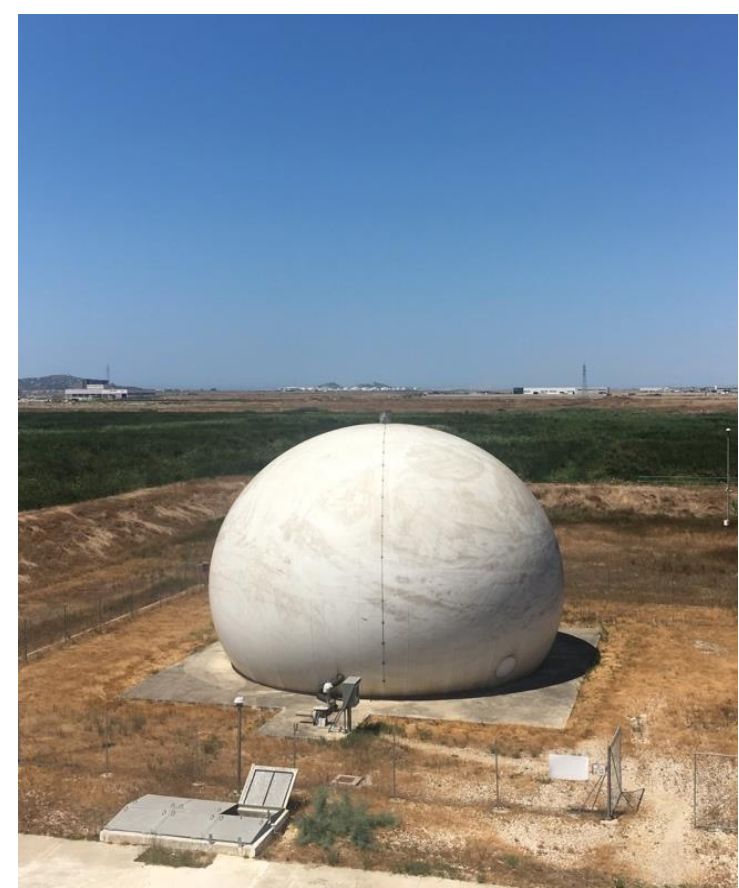

Fig. 1. Biogas-holder in WWTPD.

Tania Floqi, Department of Engineering and Architecture, Faculty of Engineering, Informatics and Architecture, UE Tirana, Albania.

(e-mail: floqitania@yahoo.com)

Julian Sefa, Environmental Engineer, Durrës, Albania.

(e-mail: Juliansefa@ ${ }^{@}$ gmail.com). 


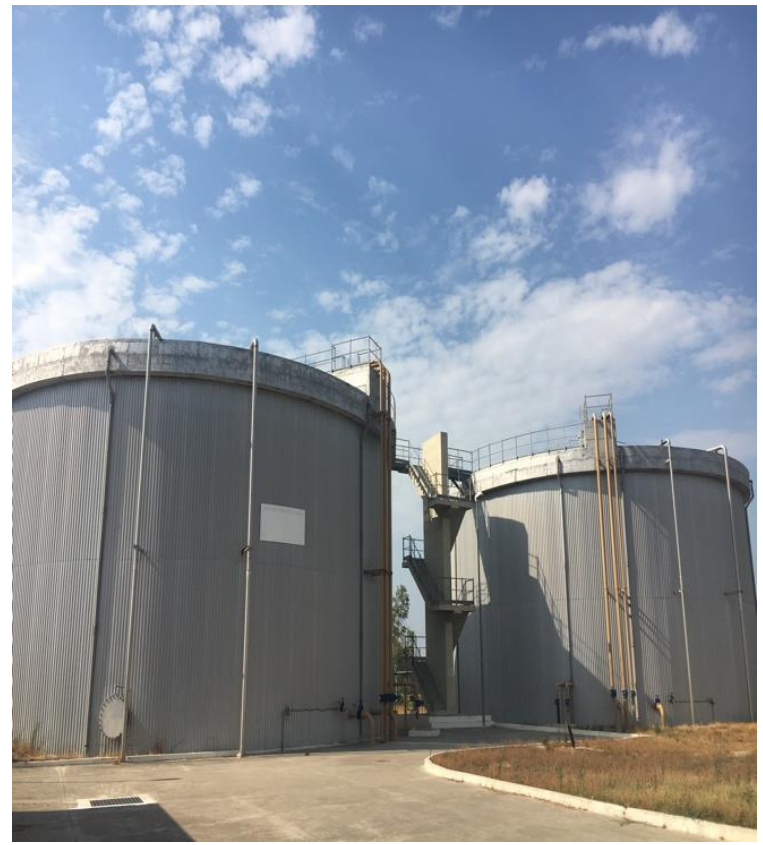

Fig. 2. Anaerobic Digestion tanks in WWTPD.

According [3] biogas produced by the wastewater treatment plant contain roughly $55 \div 70$ percent methane and $30 \div 45$ percent carbon dioxide and traces amounts of hydrogen gas, hydrogen sulphide, ammonia (all together about $1 \div 2 \%$ ) and small traces amounts of carbon monoxide, nitrogen, and oxygen. The percentage of these gases depends on the sludge composition, temperature, $\mathrm{pH}$, and pressure [4].

TABLE I: THE PERCENTAGE OF $\mathrm{CH}_{4}$ AND $\mathrm{CO}_{2}$ ACCORDING TO THE

\begin{tabular}{lcc}
\multicolumn{3}{c}{ LITERATURE } \\
\hline According to [5] & $60 \% \mathrm{CH}_{4}$ & $40 \% \mathrm{CO}_{2}$ \\
According to [6] & $55 \div 70 \% \mathrm{CH}_{4}$ & $30 \div 45 \% \mathrm{CO}_{2}$ \\
According to [7] & $63 \div 67 \% \mathrm{CH}_{4}$ & $33 \div 37 \% \mathrm{CO}_{2}$ \\
\hline
\end{tabular}

Qualitative parameters for measuring biogas are the amount of methane $\mathrm{CH}_{4}$ and carbon dioxide $\mathrm{CO}_{2}$, but also other gases in the form of traces. The percentage of these gases depends on the composition of the sludge, temperature, $\mathrm{pH}$, and others. Since the dissolution of $\mathrm{CO}_{2}$ depends on the $\mathrm{pH}$, its fluctuations can change the percentage of gas. The amount of biogas produced for biofuel and then electricity is measured by $\% \mathrm{CH}_{4}[8]$.

\section{MATERIAL AND METHODS}

The biogas is collected from the anaerobic digestion tank. Samples were taken at the digester tank outlet, according to IS/ISO 14853 [9]. Methods for determining percentages are instrumental and volumetric. In this paper is used the volumetric method for the determination of $\mathrm{CO}_{2}$, where $\mathrm{CH}_{4}$ is then found as the difference with $\mathrm{CO}_{2}$ (assuming that the amount of other trace gases is very small, negligible). For this purpose, was used the ORSAT apparatus, with the method of absorbing gas in an alkaline solution.

$$
\begin{aligned}
& \% \mathrm{CO}_{2}=\frac{\left(\mathrm{V}_{1}-\mathrm{V}_{2}\right) \times 100}{\mathrm{~V}_{1}} \\
& \% \mathrm{CH}_{4}=\% 100-\% \mathrm{CO}_{2}
\end{aligned}
$$

$\% \mathrm{CO}_{2}$ - percentage of $\mathrm{CO}_{2}$ in the biogas sample;

$\% \mathrm{CH}_{4}$ - percentage of $\mathrm{CH}_{4}$ in the biogas sample;

$\mathrm{V}_{1}$ - initial volume of biogas;

$\mathrm{V}_{2}$ - the volume of biogas after passing into the $\mathrm{KOH}$ solution.

In order to have the highest quality biogas production, have been controlled its parameters keeping under control the anaerobic digestion process and $\mathrm{pH}$ in the anaerobic digestion reactor.

\section{RESULTS AND DISCUSSIONS}

Biogas produced by the Wastewater Treatment Plant in Durres contains methane gas $\mathrm{CH}_{4}$, carbon dioxide $\mathrm{CO}_{2}$ and other trace amounts of gases. From the analysis performed during the three years period (2016-2017-2018), the $\mathrm{pH}$ was in normal and stable values. The $\mathrm{pH}$ values of the sludge in the digester tank were within normal close to 7.0 with the range 7.47-7.58. This has affected the good quality of biogas with a satisfactory percentage of $\mathrm{CH}_{4}$. Table II presents the average production values calculated by study year as well as the percentage of $\mathrm{CH}_{4}$ and $\mathrm{CO}_{2}$ for each year.

Table II presents the average production values calculated by study year as well as the equivalent amounts in electrical energy for each year.

\section{TABLE II: BIOGAS QUALITY OF WWTPD}

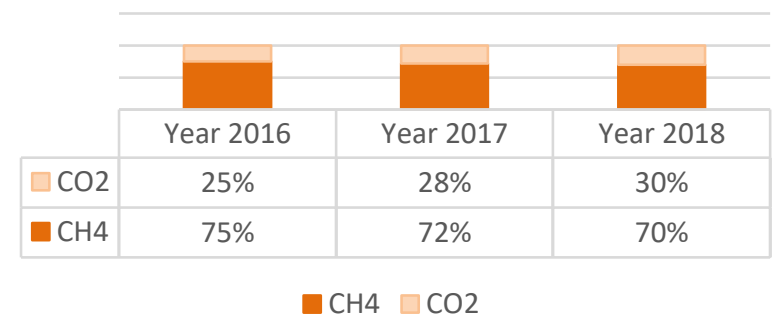

In 2016, where the amount of biogas was higher, its quality is in the ratio $75 \% \mathrm{CH}_{4}$ and $25 \% \mathrm{CO}_{2}$. Referring [10] this year had the best parameters in terms of sludge in the digester tank. A small decrease in the amount of $\mathrm{CH}_{4}$ is seen in the other two years, but the results are very good. Table III presents the average production values of biogas calculated by study year as well as the equivalent amounts in $\mathrm{m}^{3} \mathrm{CH}_{4}$ for each year.

\begin{tabular}{ccccc} 
TABLE III: BIOGAS PRODUCTION IN 2016, 2017, 2018 ACCORDING TO [10] \\
\hline Year & $\begin{array}{c}\text { Average daily } \\
\text { biogas } \\
\text { production } \\
\left(\mathrm{m}^{3} / \text { day }\right)\end{array}$ & $\begin{array}{c}\text { Average daily } \\
\text { per year of } \\
\text { methane } \\
\left(\mathrm{m}^{3} \mathrm{CH}_{4} / \text { day }\right)\end{array}$ & $\begin{array}{c}\text { Average } \\
\text { daily per } \\
\text { year } \\
(\mathrm{kWh})\end{array}$ & $\begin{array}{c}\text { Average } \\
\text { daily per } \\
\text { month } \\
(\mathrm{kWh})\end{array}$ \\
\hline 2016 & 1392.95 & 1044.7125 & 10133.71 & 844.4759 \\
2017 & 944.88 & 680.3136 & 6599.042 & 549.9202 \\
2018 & 653.34 & 457.3400 & 4436.180 & 369.6800 \\
\hline \hline
\end{tabular}

Qualitative results of biogas parameters show that physicochemical and biochemical processes were achieved under strict conditions and anaerobic digestion was carried out according to standards. The process is made in the absence of oxygen, nitrates, or sulphates. During the anaerobic digestion, the mixing of the sludge in the tank is carried out. This is a necessary and very important process because the sludge is spreaded evenly throughout the digester tank while maintaining the temperature and the spread of 
methanogenic bacteria homogeneously. The filling of the reactor is done in small quantities, so that the microorganisms have a constant concentration of organic matter, eliminating the risk of overload and increasing the concentration of volatile acids.

\section{CONCLUSION}

1) During a study period of three years the Wastewater Treatment Plant in Durres has produced a quality biogas with a percentage of $\mathrm{CH}_{4} 70 \div 75 \%$ and $25 \div 30 \%$ of $\mathrm{CO}_{2}$.

2) The optimal quality of biogas depends on the composition of the sludge, temperature, $\mathrm{pH}$ and others.

3) Qualitative results of biogas parameters in WWTPD show that physicochemical and biochemical processes were achieved under strict conditions and anaerobic digestion was carried out according to standards.

4) Quality parameters of biogas are optimal due to the solids' concentration achieved by gravity thickeners with percentage up to $2 \%$.

\section{REFERENCES}

[1] http://www.akm.gov.al/assets/impianti-i-duresit.pdf

[2] Operation and Maintenance Manual of Wastewater Treatment Plant Durres, May 2011

[3] Metcalf dhe Eddy (2013) "Wastewater Engineering: Treatment and Reuse Recovery".

[4] Hickey, Switzenbaum, 1991

[5] A. Steinhauser, "Biogas from waste and renewable resources, dieter doublein" (2008).

[6] Metcalf dhe Eddy (2013) "Wastewater Engineering: Treatment and Reuse Recovery".

[7] Derbal Kerroum, Bencheikh Le-Hocine Mossaab, Meniai Abdesslam Hassen, (2012), "Production of biogas form sludge waste and organic fraction of municipal solid waste", fq. 153-161.

[8] Stefano Marzorati, 2016 web: http://marzorati.co/quanti-kwh-permetro-cubo-di-metano/.

[9] IS/ISO 14853: Determination of ultimate aerobic diodegradability of plastic materials in and aqueous medium - Method by Measurement of biogas production.

[10] Sefa, S., Floqi, T. and Sefa, J. 2020. Measurement of Energy Production from Biogas: Evidence from the Wastewater Treatment Plant in Durres. European Journal of Engineering and Technology $\begin{array}{llllll}\text { Research. } & 5, & 10 & \text { (Oct. 2020), 1260-1262. DOI: }\end{array}$ https://doi.org/10.24018/ejers.2020.5.10.2197.

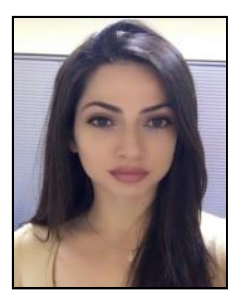

Mrs. Stela Sefa was born in Durres, Albania. She holds Master in Science degree from the Faculty of Civil Engineering at the Polytechnic University of Tirana. In 2020 she completed the PhD Program in Environmental Engineering profile with her thesis "Aspects of biomass and energy production in Wastewater Treatment Plant of Durres".

Since 2009 she is a lecturer at the Faculty of Professional Studies at "Aleksandër Moisiu" University of Durrës. In 2013 she completed a biogas specialization at the University of Applied Sciences in Bremen, Germany. Mrs. Sefa is author and co-author of scientific articles in engineering sciences and participating in national and international conferences. 